\title{
Severinas, clandestinas e as outras brasileiras: uma breve análise sobre um discurso documental feminino sobre o aborto
}

\author{
Ana Paula Penkala*
}

Resumo: O presente artigo propõe uma análise do discurso documental feminino a partir de filmes brasileiros que tratam sobre o tema do aborto. Tal recorte busca uma problematização de algumas estratégias e argumentos considerando que sejam definidores de um espaço ético e político no sentido de que evidenciam as vozes que se propõem a dar voz a um sujeito histórico (a mulher) a quem representam - as documentaristas - por meio de modos muito específicos.

Palavras-chave: discurso; feminismo; aborto; vozes; estratégias; documentário.

Resumen: El presente artículo propone un análisis del discurso documental femenino a partir de películas brasileñas que tratan sobre el tema del aborto. Tal recorte busca una problematización de algunas estrategias y argumentos considerando que son definidores de un espacio ético y político, en el sentido de que evidencian las voces que se proponen dar voz a un sujeto histórico (la mujer) a quien representan - las documentalistas - por medio de modos muy específicos.

Palabras clave: discurso; feminismo; aborto; voces; estrategias; documental.

\begin{abstract}
This article proposes an analysis of women 's documentary discourse from Brazilian films dealing with abortion. I seek a problematization of some strategies and arguments considering that they are defining an ethical and political space in the sense that they highlight the voices that propose to give voice to a historical subject (the woman) to whom they represent - women documentary filmmakers - through very specific ways.

Keywords: speech; feminism; abortion; voices; strategies; documentary.

Résumé : Cet article propose une analyse du discours documentaire féminin à partir de films brésiliens traitant de 1 'avortement. Ce biais cherche à problématiser certaines stratégies et certains arguments car ils définissent un espace éthique et politique en ce sens qu'ils mettent en évidence les voix qui proposent de donner la parole à un sujet historique (la femme) par celles qui les représentent - les femmes documentaristes à travers des moyens très spécifiques.

Mots-clés : discours ; le féminisme ; l'avortement ; voix ; stratégies ; documentaire.
\end{abstract}

\footnotetext{
* Universidade Federal de Pelotas, Centro de Artes, Cursos de Cinema e Cursos de Design. 96160-000, Pelotas-RS, Brasil. E-mail: penkala@ gmail.com

Submissão do artigo: 26 de maio de 2018. Notificação de aceitação: 19 de julho de 2018 .
} 


\section{O útero como espaço político: o Brasil e o Cavalo de Tróia}

Os países da América Latina tem algumas das legislações mais restritivas do mundo com relação ao aborto. Nos interstícios da lei estão dados sobre morbimortalidade materna, mortes em decorrência de abortos inseguros (e clandestinos) e embates políticos e sociais que revelam uma cultura punitivista de natureza misógina e profundamente embasada em preceitos religiosos e sedimentada sobre estruturas políticas de poder. Os embates políticos no Brasil sobre a questão do aborto tem base em uma cultura patriarcal, o que parece evidente, porém estruturam-se, atualmente, sobre duas heranças importantes: o atraso decorrente de mais de 20 anos de Ditadura (Civil-)Militar e a ascensão das igrejas neopentecostais no país e sua estreita relação com a política e com os meios de comunicação. ${ }^{1}$ Desde o Golpe Militar de 1964 até o final desta ditadura (1985), a discussão sobre o aborto foi atrasada em muitos pontos, na contramão das mudanças culturais que acontecem especialmente a partir da segunda onda feminista e do ativismo pelos direitos reprodutivos das mulheres e direitos civis em vários lugares do mundo. Esses movimentos sociais são responsáveis pela legalização da interrupção voluntária da gravidez (até a 12a semana de gestação) em países como os EUA (1973) e a França (1975). O debate sobre o aborto durante o último regime militar brasileiro esteve entre outras reformas culturais atrasadas em função da repressão de qualquer discussão democrática. Na mesma lógica de retrocessos, o crescimento (em número, em abrangência demográfica e em capital financeiro) das igrejas neopentecostais (chamadas de "evangélicas", comumente) a partir dos anos 1970 no país não é apenas uma questão simbólica. O patrimônio financeiro das principais igrejas desse dogma começa a ficar evidente quando passam a obter concessões de veículos de comunicação (rádio, TV e jornais impressos) e a financiar campanhas políticas importantes, elegendo deputados, senadores e governadores, assim como formando partidos. ${ }^{2}$

$\mathrm{O}$ atraso na abordagem democrática do aborto no Brasil e a influência política (nos mais diversos níveis) das bancadas religiosas convergem para um processo que encaminha o país para ser um dos mais restritivos do mundo. Em novembro de 2017, uma comissão especial da Câmara de Deputados formada para discutir uma extensão da licença maternidade em casos de bebês prematuros aprovou uma Proposta de Emenda Constitucional (PEC) que define que "a

\footnotetext{
1. Ver mais em: www.revistamissoes.org.br/2017/07/igrejas-neopentecostais-e-a-midiatiz acao/

2. Sobre o crescimento da bancada evangélica nos Poderes políticos do Brasil, ver: www. cartacapital.com.br/revista/811/alem-do-misticismo-9696.html
} 
vida começa na concepção". Chamada de PEC "Cavalo de Tróia" 3 , a Proposta 181/2015 pretende alterar dois artigos da Constituição Federal, significando um retrocesso de muitas décadas nos direitos reprodutivos da mulher. ${ }^{4}$ Numa comissão formada para trazer um benefício para mães de prematuros, a aprovação de uma PEC com esse teor revoga dois direitos concedidos às brasileiras ainda em 1940 e um conquistado em 2012: o aborto não é criminalizado em casos de gestação em decorrência de estupro ("aborto sentimental") e nos casos em que a gestação põe a vida da mulher em risco ("aborto terapêutico"); e a interrupção voluntária da gravidez também é permitida em casos de anencefalia do feto.

Tais questões políticas são o campo do embate simbólico na produção documental no mundo todo a respeito do tema do aborto, refletindo uma polarização que divide o debate: ou se é "pró-vida" (pro-life), ou se é "pró-escolha" (pro-choice). A possibilidade de neutralidade sobre o aborto parece tão impossível quanto a possibilidade de um documentário que represente essa neutralidade. Mesmo as reportagens "informativas" sobre o tema revelam estratégias discursivas em que a linguagem audiovisual está a serviço de um posicionamento. Na reflexão teórica sobre o documentário, parece ser ponto pacífico que não se trata de uma prática isenta, nem como dispositivo, nem tecnicamente, como sugere a afirmação de Bill Nichols (2005a: 26-7):

Esses filmes representam de forma tangível aspectos de um mundo que já ocupamos e compartilhamos. Tornam visível e audível, de maneira distinta, a matéria de que é feita a realidade social, de acordo com a seleção e a organização realizadas pelo cineasta. Esses filmes também transmitem verdades, se assim quisermos.

O que este artigo propõe é uma análise sobre algumas práticas discursivas e estratégias e procedimentos documentais através de três documentários brasileiros sobre o aborto, todos eles observados a partir da premissa de que argumentam em favor dos direitos reprodutivos das mulheres e de escolha. As análises aqui apresentadas fazem parte de uma pesquisa sobre a representação da mulher no audiovisual a partir da linguagem e das narrativas, dentro de uma abordagem dos estudos feministas. O tema - as opiniões sobre a questão do aborto - é um dos mais importantes para o feminismo. Abordá-lo a partir dos dispositivos do documental é uma proposição que leva em consideração

3. Em remissão à estratégia bélica dos gregos para invadir a cidade de Troia, fortemente fechada, enviando aos troianos um cavalo de madeira com soldados dentro da "barriga" - segundo conta Homero em passagem da Odisséia. O "presente de grego" dos deputados federais no Brasil foi um expediente político que tem caracterizado o universo masculino predominante na política do país.

4. http://justificando.cartacapital.com.br/2017/11/23/pec-do-cavalo-de-troia-como-arma-c ontra-as-mulheres/ 
algumas relações inequívocas entre a prática documental e uma concepção de função social que a perpassa (Ramos, 2005).

A escrita deste artigo carrega traços de uma militância feminista, pressuposta na anteriormente assumida abordagem teórica, e faz parte da própria busca pelo olhar documental de mulheres, sobre mulheres. Não se ignora aqui, portanto, que a escolha do tema e dos produtos analisados sejam reflexos diretos dessa posição, sendo assim submetidos à mesma premissa da qual se parte aqui com relação à natureza da prática documentária, da conhecida definição de John Grierson, para quem o documentário é um tratamento criativo da realidade (ver Nichols, 2005a: 51, e Penafria, 2005). O recorte apresentado por esta abordagem baseia-se tanto no fato de serem narrativas sobre questões da experiência íntima, social, cultural e histórica de ser mulher, assim como enfatiza a relação entre o tipo de discurso e o posicionamento revelado por ele e quem os constrói (direção, direção de fotografia, produção, roteiro, etc.). O que está em jogo, no entanto, não é a validade dos sentidos produzidos por esta análise, mas discutir sobre os procedimentos e estratégias documentais a partir dos conceitos delimitadores do campo dos estudos feministas e seus enviesamentos. Não é uma proposição aqui trazer uma amostragem que possa dar conta de uma abrangência metodológica e quantitativa dos documentários sobre aborto, mas observar de que forma esses discursos se relacionam com quem os produz e que efeitos de sentido provocam. Cada documentário será analisado a partir de suas estratégias narrativas e de linguagem, de modo que se possa compreender o fazer documental como uma verdade, assim também como enquanto uma voz. Os filmes escolhidos para esta análise são brasileiros, dirigidos e/ou produzidos por mulheres, e estão disponíveis no YouTube. O recorte sobre filmes brasileiros que sejam dirigidos por mulheres tem relação com o contexto histórico do país, mas serve como um exemplo para a luta das mulheres ao redor do mundo, mesmo em países em que o aborto é permitido por lei.

Outra das premissas desta abordagem é a de que documentários de mulheres sobre mulheres constituem-se como um argumento de resistência sobre a realidade, no sentido de que são narrativas que tensionam o olhar instituído, neutralizador, masculino; ilustrando a importância da escrita de uma história das mulheres contada pelas mulheres. Ao estabelecer a opção teórica de tratar de patriarcado (em "detrimento" do conceito de gênero) enquanto um sistema que, entre outras coisas, exclui essas vozes e essas histórias, o artigo também estabelece uma relação de filiação com as vertentes mais radicais da teoria crítica feminista, especialmente àquelas que pensam a dominação das mulheres pelos homens a partir da interdependência entre a realidade reprodutiva, a 
opressão sexual e a acumulação primitiva. Não apenas pela sua vinculação teórica, o texto se constrói também em sua relação com os objetos analisados, que tratam de temática crucial em que esses conceitos dialogam.

Desde o início do movimento das mulheres, as ativistas e teóricas feministas viram o conceito de "corpo" como uma chave para compreender as raízes do domínio masculino e da construção da identidade social feminina. [...] Desse modo, a análise da sexualidade, da procriação e da maternidade foi colocada no centro da teoria feminista e da história das mulheres. (Federici, 2017: 31-32)

Neste sentido, a compreensão do conceito de patriarcado toma por fundamento a acepção admitida por Heleieth Saffioti (2015), para quem o conceito não está relacionado ao direito do poder paterno mas ao direito sexual (ao corpo feminino), o que também é crucial para a discussão aqui proposta. Quando se discute as estratégias de resistência a uma estrutura patriarcal, a questão do aborto é um modelo a partir do qual é possível que entendamos uma realidade hierárquica onde a lei é instrumento não de um pensamento moralista judaico-cristão, mas de um dispositivo sexual de dominação para o qual a mulher é um corpo-objeto que deve servir às engrenagens desse sistema. Isto é dizer que as estratégias documentais manejadas nos filmes analisados estão sendo consideradas como parte do tecido das narrativas femininas sobre si (ou sobre nós, Outras), o qual evidencia e denuncia, na esteira do que nos permite pensar Silvia Federici, "[...] as estratégias e a violência por meio das quais os sistemas de exploração, centrados nos homens, tentaram disciplinar e apropriar-se do corpo feminino, destacando que os corpos das mulheres constituíram os principais objetivos [...] para a implementação das técnicas de poder e das relações de poder" (2017: 32).

\section{O “Outro" que aborta e o jogo de cena do documentário}

Os documentários sobre aborto no Brasil dão a ver a situação política em que a questão se encontra atualmente. Um dos centros do debate sobre o tema é o alto número de mulheres mortas em decorrência de abortos clandestinos, o que tem relação fundamental com o tipo de abordagem documentária nesse âmbito. A maioria dos documentários brasileiros sobre o tema argumenta no sentido de criar ou subsidiar debates acerca das consequências da situação da ilegalidade da prática, posicionando-se como "pró-escolha" e assumindo um discurso que quase sempre é autorreferente, reiterando seus procedimentos formais como uma espécie de tradução da polaridade que se constrói em torno das controvérsias morais relacionadas à descriminalização do aborto. O tipo de ponderação nesses documentários segue uma lógica que tem sido observada 
mesmo em produções de países onde a prática é legalizada, como se vê no recente vídeo norte-americano - Abortion Stories Before Roe v. Wade ${ }^{5}$, que considera a real ameaça ao direito ao aborto gerada pelas políticas implementadas pelo governo de Donald Trump desde $2017^{6}$. Duas produções brasileiras exploram o consenso de que a ilegalidade da interrupção voluntária da gestação não impede que mulheres o façam (algumas optando por procedimentos perigosos, na maioria das vezes impulsionadas por desespero): Clandestinas $^{7}$ (2014), dirigido por Fadhia Salomão, ${ }^{8}$ e $O$ aborto dos outros ${ }^{9}$ (2008), com direção de Carla Gallo. Ambos os filmes, no entanto, constroem seu discurso de modo diferente, enfatizando-o a partir de escolhas estéticas e de linguagem diversas.

Dirigidos e produzidos por mulheres, Clandestinas ${ }^{10}$ e $O$ aborto dos outros são construídos no contexto das lutas feministas pelos direitos femininos sobre o próprio corpo. O subtexto de ambos diz que brasileiras vão continuar fazendo abortos - quer o Estado as criminalize ou não - e que a ilegalidade não apenas não faz sentido como propicia mortes que poderiam ser evitadas. Nos interstícios de ambos os documentários estão os argumentos em torno da necessidade de combater uma hipocrisia generalizada sobre o tema mas, principalmente, de se compreender a criminalização do aborto como uma questão de classe - tanto da classe mulher quanto referente à classe econômica, que é um dado comum à maioria das vítimas fatais de abortos clandestinos.

A complexidade política brasileira com relação aos direitos das mulheres é revelada pela desproporção entre o atraso no debate sobre o aborto e a rapidez com que são aprovadas propostas, medidas ou mesmo leis que criminalizam todos os tipos de aborto e tornam a interrupção voluntária da gestação crime

5. Histórias de aborto antes de Roe vs. Wade, produzido por "The Scene" e disponível em: https://youtu.be/vlAR8IsvCfM

6. A produção tem pouco mais que seis minutos e traz quatro depoimentos de mulheres (já idosas) que fizeram abortos ou conviveram com as consequências de abortos quando a prática ainda era proibida nos EUA. Suas falas convergem todas para o ponto em comum, no qual as mulheres expressam apreensão pela possibilidade de um retorno à ilegalidade do aborto no país. O elemento extratextual fundamenta o temor, pois desde que foi empossado, Donald Trump assumiu um posicionamento combativo com relação a políticas de planejamento familiar e esteve aberto a demandas conservadoras por restrições cada vez maiores ao direito ao aborto, vigente desde o caso Roe vs. Wade, em 1973, a partir do qual se legalizou a interrupção da gravidez nos EUA até o limite da viabilidade do feto. O corte no orçamento para a organização Planned Parenthood, responsável por prover abortos gratuitos para mulheres sem condições de pagar pelo procedimento em alguma das muitas clínicas licenciadas no país, foi um dos primeiros passos de Trump no sentido de uma política marcada pelo ataque aos direitos de minorias. Ver mais em: www.washingtonpost.com/news/post-nation/wp/2017/05/23/trumps-budgetproposal-aims-to-cut-all-federal-funds-from-planned-parenthood/?utm_term=.c8e1db49f86f.

7. Disponível em: https://youtu.be/AXuKe0W3ZOU

8. Roteiro de Renata Correa e produção de Babi Lopes.

9. Disponível em: https://youtu.be/de1H-q1nN98

10. O filme foi feito a partir de uma iniciativa de mulheres que contou com apoio de equipe quase toda feminina e financiamento obtido a partir de ONGs e coletivos de mulheres. 
passível de punições ainda mais severas. Recentemente, as frentes parlamentares das quais fazem parte os partidos religiosos conseguiram outra forma de aprovar suas principais pautas. Enquanto tramitava a denúncia de corrupção passiva contra o Presidente Michel Temer apresentada pela Procuradoria-Geral da República, parlamentares desses partidos negociaram seus votos na inadmissibilidade das acusações (o que torna a denúncia improcedente) em troca de terem suas demandas atendidas. ${ }^{11}$ Uma delas é a do Estatuto do Nascituro, que torna o aborto (em qualquer caso) crime hediondo e prevê punições inclusive para as mulheres que passarem por abortos espontâneos. O Projeto de Lei 478/2007 (PL 478/2007) representa um retrocesso mesmo frente a outras legislações mais fechadas, incluindo a possibilidade de estupradores constarem na certidão de nascimento como "pais". O Estatuto do Nascituro ser usado como moeda política em troca de arquivamento de denúncias de corrupção é uma consequência da ausência de debate sobre a questão do aborto e dos direitos reprodutivos da mulher no Brasil. No caos político em que se encontra, a discussão sobre o aborto revela estratégias políticas paradoxais. Algumas estratégias documentais buscam fazer remissão a esse paradoxo ao utilizar a cultura como fonte dessas contradições.

A começar pelos seus títulos, esses filmes evocam uma certa tradição cultural de relegar o aborto a uma alteridade abstrata, quase alegórica, que é indício das forças em jogo relacionadas à prática, forças estas que tem origem na própria estruturação social de um país fortemente atravessado pela moralidade cristã e profundamente patriarcal. Diferente do que vem sendo discutido há muito em grande parte da Europa e nos EUA, o cerne nebuloso da "questão do aborto" no Brasil ainda é uma motivação de natureza misógina que é obliterada, por sua vez, pela narrativa religiosa e mítica erigida para cumprir um papel pragmático na construção de uma sociedade capitalista e de controle. O que Michelle Perrot diz sobre a França (e, em grande medida, sobre a Europa) depois da Idade Média ainda repercute vividamente nos arranjos sociais e civis brasileiros: "Como a função materna é um pilar da sociedade e da força dos Estados, torna-se um fato social. A política investe no corpo da mãe e faz do controle de natalidade uma questão em evidencia" (2017: 69). No início do século XX, a prática, que era cada vez mais coibida em nome da moralidade, porém ainda era tolerada, passa a ser denunciada naquele país como responsável pela diminuição da população - o que acarreta uma perda de força de trabalho e produção - e, com as baixas da Primeira Guerra Mundial, tanto o aborto quanto qualquer método anticoncepcional passam a ser

11. https://noticias.uol.com.br/ultimas-noticias/agencia-estado/2017/07/31/frentes-usam-de nuncia-para-pressionar-temer.htm 
reprimidos e condenados. Segundo Federici, a transformação das mulheres em "[...] máquina de produção de novos trabalhadores" (2017: 26) é central no processo de acumulação capitalista. O que muitos dos documentários sobre a criminalização das mulheres com relação ao aborto acabam por denotar é que o recrudescimento do controle do corpo feminino sempre atrelado a ondas conservadoras não encontra obstáculos dada a imaturidade do debate sobre a questão. Esses documentários buscam na militância estratégias novas de inserir a discussão ao menos entre aqueles que imaginam que a violência misógina pertence a um passado desse processo de acumulação. Como menciona ainda Federici, a despeito do que pensava Marx,

cada fase da globalização capitalista, incluindo a atual, vem acompanhada de um retorno a aspectos mais violentos da acumulação primitiva, o que mostra que a contínua expulsão dos camponeses da terra, a guerra e o saque em escala global e a degradação das mulheres são condições necessárias para a existência do capitalismo em qualquer época. (2017: 27).

Essa reflexão é importante no sentido de que as produções aqui analisadas desenvolvem estratégias através das quais é possível perceber " $a$ voz" (Nichols, 2005b) desses documentários, que engendra relações entre os procedimentos discursivos e a crítica feminista. É possível perceber nesses filmes as evidências de um feminismo que exercita a alteridade, buscando equilibrar os lugares de fala de dois tipos de mulher: aquela que forma o corpo social (e material) da problemática da criminalização do aborto no Brasil e aquelas que formalizam essa denúncia no discurso documental. As primeiras, mulheres que fazem parte das estatísticas de violência, as vítimas das consequências da precariedade do sistema de apoio que dá conta dos abortos previstos em lei e as que buscam na ilegalidade a solução desesperada para uma gestação que não deve acontecer; e as segundas, mulheres que vem de um estrato social representado pelas classes sociais privilegiadas, em certo sentido, e relacionadas a um tipo de feminismo acadêmico. Signos como "outra", "clandestina" e o da própria miserabilidade e marginalidade atreladas à "severina" são claros indícios de um exercício dessa alteridade - e de que alteridade é esta. Como enfatiza Bill Nichols (2005b: 50), não se trata de uma estilística, e sim daquilo "[...] que, no texto, nos transmite o ponto de vista social, a maneira como ele nos fala ou como organiza o material que nos apresenta". A voz no documental "[...] não se restringe a um código ou característica, como o diálogo ou comentário narrado. Voz talvez seja algo semelhante àquele padrão intangível, formado pela interação de todos os códigos de um filme [...]" (Nichols, 2005b: 50). Nos filmes aqui analisados, a expressão desse exercício de alteridade dá a ver o próprio embate, dentro do feminismo, entre aquelas que sabemos que fazem aborto, muitas das quais morrendo por causa de procedimentos irregulares e in- 
seguros, e aquelas que representam suas vozes inaudíveis através do ativismo e da crítica. Com relação a essas últimas, outro embate acontece, que demarca as disputas entre olhares privilegiados e olhares subalternos dentro do próprio feminismo. Nesse sentido, é importante evocarmos Djamila Ribeiro (2017), filósofa e feminista negra brasileira, quando propõe explicar lugar de fala a partir da problemática racial dentro da militância. Para isso nos relembra de Grada Kilomba - escritora portuguesa e feminista negra radicada na Alemanha - que flexiona as categorias estabelecidas por Simone de Beauvoir em $O$ segundo sexo, de onde vem a compreensão da mulher como o Outro do homem. A filósofa francesa, ao falar sobre a maneira como a psicanálise, por exemplo, trata da individuação feminina, diz que "[...] a menina não se aliena numa coisa apreensível, não se recupera; em consequência, ela é levada a fazer-se por inteira objeto, a pôr-se como o Outro" (Beauvoir, 2009: 81-2). Para Ribeiro (2017), Kilomba sofistica a análise de Beauvoir ao reforçar que a mulher negra é o Outro do Outro. Essa questão é fundamental para esses filmes, porque em todos transparece, em maior ou menor medida, a quem mais atinge a ilegalidade do aborto: mulheres pobres, negras e trabalhadoras sem instrução de comunidades pobres. E ao colocarem essa questão nevrálgica, os documentários enunciam, também, essa alternância de vozes, como se dissesse ora "nós falamos de nós para vocês", ora "nós falamos delas para vocês".

O "outros" de O aborto dos outros é, de certa forma, análogo ao "clandestinas" ao trazer à tona as vozes que são isoladas socialmente a partir da prática ilegal do abortamento. Cada um dos termos, no entanto, ilustra os dispositivos documentais usados nesses filmes. Embora não pretenda discutir a acepção de dispositivo aqui, é necessário que fique claro a compreensão (simples) da qual parto para atribuir o termo às produções analisadas. Assim, empresto de Consuelo Lins e Cláudia Mesquita (2008: 56) a sintetização da noção, que “[...] remete à criação, pelo realizador, de um artifício ou protocolo produtor de situações a serem filmadas - o que nega diretamente a idéia de documentário como obra que 'apreende' a essência de uma temática ou de uma realidade fixa e preexistente". Neste caso, as autoras estão falando de uma "maquinação" (que eu chamaria de programa), uma lógica que vai estabelecer algumas condições para que o filme seja construído. Nessa concepção, acabam por definir algo da lógica dos documentários aqui explorados, no sentido de que o dispositivo, na visão de Jean-Louis Comolli, segundo as autoras, ajudaria o documentário a se ocupar daquilo que não interessa a um pensamento enviesado das mídias. Esse procedimento, em si, pode ser reconhecido como um argumento de resistência. 
O "outro" de $O$ aborto dos outros faz uma remissão direta ao mascaramento ideológico em torno da questão, marcado pela consistente negação que insiste em manter o debate sobre o assunto como um elefante branco no centro da moralidade cristã, abstraindo dele as perdas humanas e o grande problema de saúde pública que representa. Assim, utiliza "outros" como uma lembrança irônica de que a fala que se apodera do tema é aquela para quem a mulher é um Outro. Nesse sentido, busca enquadrar alteridades pontuais, tanto solicitando revisão do distanciamento político tradicionalmente vinculado a esses Outros, quanto buscando privilegiar o lugar de fala dessas mulheres que buscam o sistema público para os abortos legalizados. Se neste filme a menção ao aborto feito com permissão da restritiva lei brasileira reforça em seu argumento a estrutura - que se impõe sobre esse Outro - que ainda controla os corpos das mulheres, em Clandestinas a "lei", a "estrutura" também é uma figura borrada e onipresente, mas já assumida desde o próprio dispositivo. A clandestinidade que impera desde o título é um signo de que este documentário dá um passo para além das bordas da estrutura, afirmando que mulheres fazem abortos ilegais e que continuam sendo mulheres como quaisquer outras, e não aberrações morais. A fala assumida por elas a partir do dispositivo, no entanto, cria um tipo de efeito dúbio. O principal argumento desta asserção é o de que há uma igualdade nessas mulheres que alude à noção de classe (da classe mulher), construindo um tecido político que busca não personalizar os atos e sim, pelo contrário, atribuí-los à condição limite de ser mulher. Na abertura do filme, sobre a voz feminina que canta a condição de ilegalidade dos abortos, vemos imagens de mulheres jovens segurando uma placa onde se lê "clandestina" e, abaixo, um número. Nas "entrevistas", em planos aproximados elas tensionam o conceito da "fala" - que dá voz a essas mulheres -, caso se saiba que algumas são atrizes (profissionais ou não) interpretando histórias de mulheres anônimas. ${ }^{12}$ Assim, acaba por fazer uma reflexão sobre os procedimentos documentais ao colocar em jogo certa tradição argumentativa segundo a qual atores sociais representam uma generalização. Se essa generalização é um importante argumento feminista no sentido de construir a classe mulher, o sujeito mulher, a partir da asserção de que ninguém sabe se somos ou não a pessoa real daquela história de clandestinidade, por um lado; por outro lado cabe pensarmos que para uma parte daqueles/as que estão vendo esses depoimentos, não fica claro que algumas são histórias de mulheres anônimas interpretadas por atrizes.

O dispositivo usado em Clandestinas retoma o programa do documentário também brasileiro Jogo de cena (Eduardo Coutinho, 2007), embora este

12. Retiradas do site https://somostodasclandestinas.wordpress.com/ 
deixe claro que envolve a história de pessoas desconhecidas interpretada por atrizes (o filme mostra depoimentos somente de mulheres). No filme de Coutinho também é explorada a relação entre a história de si e a experiência de ser mulher. "Por que só mulheres? Porque falam com mais facilidade de suas dores e alegrias, diz Coutinho; e também porque, para ele, mulheres são o que ele não é, o 'outro' que busca em seus filmes." (Lins e Mesquita, 2008: 78). Em Clandestinas, o dispositivo não molda a busca por um "outro", mas um "si mesma" presentificado em uma representação que alude a "um outro" como conceito, já que mulheres são historicamente construídas como este "outro", como nos dirá Simone de Beauvoir (2009), denunciando essa forçosa alienação das mulheres - ora são "os outros", ora são "clandestinas", ora não se sabe quem são. Talvez não por acaso Clandestinas comece com o depoimento de uma mulher negra que conta primeiro a história do aborto de uma amiga, representando-a e criando um efeito de eco que remete a uma espécie de visão em abismo, um hipertexto de outras histórias. Esse efeito vai aparecer em outras falas, como quando uma outra mulher diz que contou para a mãe sobre o aborto que viria a fazer e soube que outras mulheres conhecidas, incluindo sua vó, também haviam recorrido à interrupção da gravidez. Desenha, na arguição que o dispositivo organiza, a afirmação de que o aborto, assim como a gravidez, é próprio do ser mulher, e faz vulto na invisibilizada história das mulheres. Tensiona, nessa estratégia, conceitos como o de "lugar de fala" (Ribeiro, 2017), ao mesmo tempo ressaltando e obliterando a existência de uma radical diferença entre as várias experiências de ser mulher. $\mathrm{O}$ fato de que a maioria das mulheres que contam essas histórias são brancas (e aparentemente instruídas e de classe média) em Clandestinas não nos permite compreender se o filme opta por não relacionar a mulher negra à clandestinidade e ao mesmo tempo pretende afirmar que mulheres brancas de classe média também fazem abortos; ou se reflete um olhar de um feminismo liberal, involuntariamente endossado pelo feminismo acadêmico muitas vezes, que universaliza a categoria mulher. Nesse mesmo sentido, também é possível colocar em discussão que a mulher que abre e encerra o documentário cantando uma música cuja letra fala de "sermos mulheres clandestinas" tem fortes traços indígenas. Embora as estatísticas não sejam tão claras quanto a relação entre o abortamento clandestino e a comunidade indígena brasileira, essas mulheres são ainda mais ignoradas como sujeitos em suas especificidades dentro do feminismo que predomina nas mídias (o chamado feminismo liberal). Parece, portanto, que tomam os novos lugares reservados a elas por um olhar acadêmico, branco, privilegiado, embora não se possa afirmar que por má-fé: enquanto a mulher negra cum- 
pre seu papel no sentido de "garantir" uma "diversidade" às falas, a indígena representa uma espécie de alegoria, quase uma menção poética.

Ao falar sobre os procedimentos de interrupção de gestação permitidos juridicamente e praticados no âmbito da saúde pública no país, $O$ aborto dos outros não se compromete com o risco de cair na ilegalidade de mostrar a clandestinidade. A ênfase desse filme se dá sobre o hospital, no qual dois casos exemplares (entre outros) são escolhidos para demonstrar como funciona o acolhimento aos casos elegíveis para o abortamento legal pelo sistema público. É no hospital que conhecemos uma menina de 13 anos que, acompanhada de sua mãe, quer interromper uma gestação fruto de um estupro; e uma mulher adulta que descobre que o feto que carrega não é viável. O argumento do documentário está amparado na necessidade de um apoio que não é apenas técnico/profissional a essas mulheres, mas que demanda uma abordagem humanizada das problemáticas envolvendo o abortamento, seja ele por opção ou ocorrência involuntária. "Maria", com 13 anos, é mais uma vítima do estupro como instrumento político de opressão, representando o dado concreto sobre a vulnerabilidade de meninas e adolescentes. A segunda mulher, uma jovem adulta, negra, pobre, sofre pela necessidade de um abortamento que não é voluntário. Está conformada, no entanto. O documentário não as identifica - procedimento parecido com o que se dá em Clandestinas, porém com efeito e razão diferentes - e sinaliza através da maneira com que conduz o enquadramento de suas histórias, no hospital em que são recebidas, uma formalização da ritualização dos seus lutos, demonstrando optar pelo argumento que contraria a imagem demonizada de frieza, egoísmo e maldade com que são construídas as mulheres que abortam. A instância formal deste documentário - fotografia, montagem, etc. - assume o discurso a partir desses argumentos de maneira que enfatize que mesmo desejável, como quando se quer terminar uma gravidez fruto de estupro; ou inevitável, como quando se dá depois da morte intrauterina natural ou acidental, o aborto deixa marcas doloridas nessas mulheres e não deve ser pensado como uma opção banal. Esses procedimentos buscam humanizar as mulheres que interrompem a gravidez, mas também reforçam um assujeitamento pelo qual se pode identificá-las como tipos, como Outros de quem se fala e por quem se fala.

Em ambos os filmes, a resistência central para a luta feminista de "dar fala" às mulheres e politizar suas vidas pessoais, historicizando-as, é construída na forma de argumentos que por vezes esbarram na dificuldade de se estabelecer uma cisão entre a linguagem dominante e uma linguagem que a subverta. Essa compreensão é também primordial ao feminismo, que, como em Djamila Ribeiro (2017: 14), entende a "[...] linguagem como mecanismo de manutenção 
de poder [...]". Michelle Perrot (2017: 16) nos diz que "escrever a história das mulheres é sair do silêncio em que elas estavam confinadas". Essa afirmação ganha certo contorno mítico quando mulheres fazem documentários onde o que se discute é o aborto, em uma sociedade em que o tema é silenciado porque suas interlocutoras, advogadas e pleiteadoras são mulheres. Especialmente quando "esse aborto", enquanto história, biografia, remete a uma mulher e a muitas, a uma e a uma classe. A maneira com que as entrevistas são formalizadas nos dois documentários é uma estratégia fundamental para dizer isso. Não identificar as mulheres, ou jogar com o dispositivo no sentido de fazer-nos observar o que dizem, independente de quem está interpretando o texto, retira da entrevista seu tom particularista. Consuelo Lins e Cláudia Mesquita (2008), ao falarem sobre o documentário brasileiro contemporâneo, citam uma tendência a um tipo de recorte mínimo onde se aborda experiências individuais, de modo que se valorize uma subjetivação da pessoa comum. Clandestinas e $O$ aborto dos outros parecem seguir no caminho oposto a isso, buscando na história particular das mulheres uma generalização que é extremamente importante dados os temas discutidos. Naturalmente as micro-histórias dessas mulheres seriam percebidas como subjetivas, e não é o que se pretende ao argumentar que essas são as histórias das maiorias das mulheres e, mais que isso, sobre o "ser mulher" na nossa sociedade. Essa argumentação está dentro de um modo específico de representar a interação entre cineastas, atores sociais ou temáticas e espectadores, que Bill Nichols (2005a) traduz na expressão "nós falamos de nós para eles", onde "eles" aqui não são indivíduos, pessoas particulares, mas uma estrutura social que, neste caso, em última instância, seriam os membros das classes dominantes (homens, brancos, das classes médias e altas). Essa expressão, segundo o autor, tem uma inflexão nova a partir de expressões de extratos marginalizados da sociedade (nos quais se incluem as mulheres). "Associada ao surgimento de uma 'política de identidade' que honrava o orgulho e a integridade de grupos marginalizados ou excluídos, a voz do documentário deu uma forma memorável a culturas e histórias ignoradas ou reprimidas por valores e crenças dominantes na sociedade." (Nichols, 2005a: 193).

É interessante que tomemos a discussão aqui iniciada como não apenas algo que fala sobre as mulheres e suas práticas - uma cultura feminina, tradicional e/ou revolucionária - mas sobre o documentário em si. Com pouca participação na realização audiovisual, as mulheres pleiteiam espaço em um universo desigual dominado especialmente pelas produções de ficção, nitidamente por tratar-se de um mercado ou uma indústria fortemente dependente da cultura capitalista, que sempre foi, também, a cultura patriarcal. Não por acaso, é na relação estreita entre produção documentária e iniciativa indepen- 
dente que as mulheres encontram (e ocupam) mais espaço criativo e produtivo, como sugere o relatório Women in Independent Film, 2016-17 $7^{13}$ de Martha Lauzen, pesquisadora do Center for the Study of Women in Television \& Film, da Universidade Estadual de San Diego. Parece lógico que o olhar documental seja influenciado por um "olhar feminino", onde as representações propõe deslocamentos, via linguagem geralmente, de um olhar privilegiado, dominante, discursivamente empoderado e naturalizado, como nos demonstra Laura Mulvey (1989) em texto fundamental em que reforça o caráter político do olhar. Para ela, o olhar masculino não é o olhar de um homem, mas um posicionamento, um lugar discursivo. Perrot (2017), citando o livro Images de femmes, de Georges Duby, fala sobre como os homens reduzem as mulheres a espectadoras de si mesmas. Para a autora, a diferença entre os sexos estrutura a linguagem do cinema. É um olhar masculino que representa as mulheres no cinema (assim como em todas as artes), e esse olhar é redutor. Apesar de representada à exaustão, o mistério (para usar um termo de Perrot) sobre a mulher predomina, especialmente porque não são elas, em sua maioria, quem contam suas histórias. Os documentários aqui analisados podem ser pensados como tendo como dispositivo primeiro, primordial, a retomada da palavra, a busca por contar a história das mulheres pelo olhar feminino, que também revela uma tradição de contação de histórias enquanto uma "escrita privada" (Perrot, 2017). O texto sobre o aborto é transformado em público apenas no discurso da estrutura regulatória (jurídica, médica, civil), que é masculino, enquanto que permanece um "detalhe" íntimo quando se chega a suas consequências materiais e materializadas no corpo e na vida de uma mulher. O que estes documentários propõem é inverter essa lógica.

Uma das estratégias de $O$ aborto dos outros é construir os atores sociais de modo que suas vidas, experiências ou existências sejam exemplares para o argumento que o documentário busca sustentar. Em alguns casos, a estratégia dupla neste filme é a de primeiro construir o sujeito histórico a partir do qual o aborto pode ser discursivamente pensado como um direito humano, civil, político - ou um instrumento político de controle das mulheres. Somente a partir daí é que propõe discutir questões particulares. Assim é quando este documentário abre sua asserção apresentando a circunstância de uma menina de 13 anos estuprada e grávida. Embora o argumento de um documentário que trata principalmente de abortos legalizados não precisasse conter a defesa de uma prática regulamentada, trata-se de uma advocação necessária uma vez que a interrupção da gravidez é considerada um ato cruel contra um em-

13. Disponível em: http://womenintvfilm.sdsu.edu/wp-content/uploads/2017/05/2016-17_ Women_in_Independent_Film_Report.pdf 
brião/feto/criança ainda que o estupro que a gerou seja uma violência contra um ser humano. Assim, este documentário busca mostrar que a violência sexual oprime as mulheres e obrigá-las a gestar e parir filhos dessa violência seria uma prática abominável do Estado.

A despeito desse viés, que creio ser uma intenção presente em boa parte dos documentários "pró-escolha", é possível notar uma voz que estabelece uma espécie de hierarquia que pode revelar o fracasso de uma representação que não se problematiza, que não coloca seus procedimentos em cheque. Recupero essa discussão trazendo novamente o conceito de "voz".

Muitos cineastas contemporâneos parecem ter perdido a voz. Politicamente, renunciam à própria voz em favor da de outros (em geral, personagens recrutados para o filme e entrevistados). Formalmente, rejeitam a complexidade da voz e do discurso pela aparente simplicidade da observação fiel ou da representação respeitosa, pela traiçoeira simplicidade do empirismo não questionado (do tipo: as verdades do mundo existem; só é preciso tirar-lhes a poeira e relatá-las). [...] Poucos estão preparados para admitir, através do tecido e da textura de sua obra, que todo filme é uma forma de discurso que fabrica seus próprios efeitos, impressões e pontos de vista. (Nichols, 2005b: 50)

O aborto dos outros começa já nos apresentando Maria (a adolescente de 13 anos), de costas, durante a entrevista com a psicóloga do hospital. A partir daí, vemos muitas mulheres em cena: o depoimento da mãe de Maria à psicóloga, médicas e enfermeiras que fazem os primeiros procedimentos da internação, pacientes de pré-natal, em uma movimentação que descreve esse espaço como de forte relação com a experiência feminina. É possível pensar, no entanto, que o hospital, enquanto instituição, representa o lugar em que se cruzam as vozes da ciência e da lei. Ao centrar as entrevistas nesta instituição, o documentário evidencia essa relação hierárquica. Quando o primeiro homem aparece em cena, trata-se de um médico que revela, através de um ultrassom, que o bebê de uma outra mulher tem duas mal formações que inviabilizam sua sobrevivência. As tomadas, até o momento, são muito fechadas e em alguns momentos a câmera faz movimentos descritivos que desenham na tela a condição mais derradeira do ser mulher, que é o corpo feminino. Para um documentário que fala sobre abortos, o corpo feminino é um signo de onde se pode construir os sentidos da materialidade da experiência atravessada por uma opressão estrutural e sistêmica. A câmera exerce um poder complexo sobre esses corpos e essas identidades femininas, ora possibilitando que pensemos na denúncia da condição a que esses corpos são submetidos, ora incorrendo na fetichização desses corpos, os quais confina e fragmenta sob o olhar que parece prender as mulheres em sua condição primeira, de realidades biológicas e de Outros, e não sujeitos. Apesar de uma teoria bastante criticada 
dentro do feminismo por seu viés dito determinista, ainda é possível convocarmos alguns aspectos importantes da perspectiva de Mulvey (1989) a respeito do olhar que o cinema produz. Em especial quando reflete sobre o inconsciente patriarcal que estrutura a narrativa cinematográfica a partir de conceitos freudianos conhecidos, como escopofilia e fetichismo. A operação masculina e heteronormativa presente no olhar revelado pelas imagens do cinema tradicionalmente garante a manutenção da hierarquia para a qual homens são ativos e mulheres são passivas. O homem é o sujeito da ação, é quem olha, e a mulher é a imagem, o objeto. Por vezes, é possível perceber que a câmera em $O$ aborto dos outros constrói essas mulheres como corpos, no limite entre a subversão de suas condições abstratas em favor de uma materialização de suas dores e a reiteração de suas condições de objeto, imagem - especialmente quando a câmera os fragmenta, tirando deles sua identidade, sua condição de subjetividade.

Na primeira metade deste documentário, existe uma relação de discursos e de representações dentro de seu dispositivo que torna evidente a realidade que cerca a questão no Brasil. A situação material da experiência da mulher está entre (e muitas vezes, atravessada por e restrita por) uma ciência e os saberes dos homens, especialmente o discurso da medicina e a maneira pela qual constroem o aborto enquanto uma prática técnica, científica, médica e hospitalar; e o sistema judiciário, costurado pelas leis e pelo juízo de representantes políticos. Ambas as instâncias são apresentadas - mostradas ou não no documentário - por figuras masculinas, que representam o universo masculino responsável pelas vozes da ética, por um lado, ou pelas tomadas de decisão que envolvem a legalidade, por outro. A figura feminina, seja ela a psicóloga, a mãe, as enfermeiras, as mulheres grávidas, ora aparece como cuidadora, responsável pela manutenção do bem-estar, pelo cuidado com o outro; ora aparece como depositária da injustiça do aborto: seja qual for a circunstância, seja previsto por lei ou não, o aborto é sempre uma violência para quem passa por ele. As figuras masculinas, no entanto - o pai de Maria, que não aparece, assim como o companheiro da mulher cujo bebê tem mal formações, que não a acompanha; o estuprador, que aparece como uma menção; o médico e a equipe que faz o procedimento de dar a injeção letal no feto; o médico que dá o depoimento sobre a ética que ele segue (por fazer o melhor para esta mulher) e o juiz, também mencionado - são todas ou detentoras de poderes de sanção, interdição, decisão técnica sobre o aborto; ou são ausências de caráter ético que denunciam a solidão dessas mulheres quando passam por tais sofrimentos. O papel da mulher, construído pelo documentário, é o do sofrimento, do acolhimento, do cuidado, do apoio; todos relacionados à condição reprodutiva da mulher, sua condição última. Quanto aos homens, lhes cabe o 
bastião heroico do ato médico de fornecer laudos que atestem inviabilidade de um bebê, ou de fazer um aborto que encerra um exercício de poder científico sobre o corpo dessas mulheres, uma instrumentalização técnica de sua relação com essas pessoas do sexo feminino; ou a ausência na forma de seu papel muito breve na fecundação, ou o poder de interdição ou liberação.

Ao particularizar a breve história da internação de Maria para fazer o procedimento no hospital, $O$ aborto dos outros poderá universalizar o caso de meninas de 13 anos que são obrigadas a carregar filhos quando ainda são crianças. Ao preservar a identidade de Maria, intercala a voz off da adolescente, quase sempre falando de forma muito comedida, com a imagem e depoimento da mãe, que a acompanha. Realiza, a partir de uma restrição legal (já que Maria é menor de idade), seus procedimentos assertivos no sentido de conduzir o olhar do espectador para a humanidade ali exposta em sua maior vulnerabilidade. A infância mal acabada de Maria está aparente na mãe inconformada que a apoia, ciente de sua tragédia; no plano de detalhe que mostra a adolescente desenhando com lápis de cor uma árvore estilizada em um caderno pautado escolar; e, na saída do hospital, no corpo miúdo da menina de cabelo longo e solto sobre os ombros, e que veste um abrigo de malha que denuncia sua faixa etária. Nesta tomada, mostrando mãe e filha de costas, atravessando os corredores do hospital até chegarem na rua, vemos Maria andando em passos tímidos enquanto a mãe, despachada, segura as bolsas com os pertences e faz menção de proteger a filha de atravessar a rua.

O primeiro médico entrevistado neste filme é quem dá um veredito sobre o aborto que acaba de fazer como uma decisão ética e amparada juridicamente. Os discursos contrastam: a abordagem das mulheres se dá através do emocional, na busca por empatia por parte dos/as espectadores; enquanto ao abordar homens - neste caso, médicos, especialistas na área, detentores do saber científico e de poder hierárquico no hospital e mesmo na área, entre enfermeiras e psicólogas - o documentário busca um amparo que é da ordem dos valores institucionalizados (o saber científico, por exemplo) ou das instâncias reguladoras e normatizadoras (o poder judiciário). Na terceira vez em que vemos um médico na tela, ele está ouvindo os depoimentos de sua equipe multidisciplinar, a qual argumenta em favor de mulheres que chegaram ao hospital pleiteando um aborto e relatando violência sexual. Em planos descritivos alternados com planos médios das mulheres, o documentário constrói uma metáfora na qual essas defesas soam como em um tribunal, em que a menção a elas funciona como a menção a uma classe (as mulheres) e a equipe tem a função da defesa de uma causa, refletindo os dizeres que o documentário assume como seus através da forma como organiza esses discursos. No entanto, é mais uma vez um médico, 
homem, o sujeito que ouve essas "defesas" e tem o poder de sancionar a interrupção da gestação das mulheres. Isso é algo que $O$ aborto dos outros acaba repetindo outras vezes ou como forma de enfatizar a realidade segundo a qual os destinos e os direitos reprodutivos femininos estão nas mãos de estruturas masculinas; ou, ao fazê-lo, busca falar diretamente a esses homens, na forma de um argumento de autoridade, um razoamento sobre aquilo que seria emocional e subjetivo nas situações apresentadas (seja por elas próprias ou através das histórias relatadas pela equipe). Neste último sentido, deixa a impressão de reforçar a legitimidade das estruturas contra as quais também parece oferecer denúncia.

$\mathrm{Na}$ entrevista com a mulher cujo bebê é inviável, ainda no hospital, ela menciona que planejou a criança com o marido e que, após saber da inviabilidade do bebê, optou-se pela interrupção da gestação. O jeito tímido e consternado da mulher, sentada no leito hospitalar, com a bata do hospital, potencializa seu sofrimento escondido sob uma fala conformada e até alheia quando diz que mesmo assim queria deixar nascer (por questões religiosas, inclusive). O termo usado por ela - "optou-se" - torna a demonstrar seu assujeitamento. Ela se prepara para o trabalho expulsivo de um parto induzido após a injeção que cessa os batimentos cardíacos do bebê. O procedimento é parecido com o que acontecerá com Maria. Ambas entram em trabalho de parto, o que em si lhes traz sofrimento físico e emocional.

Quase ao final do documentário, que tem cerca de uma hora e meia, há uma entrevista com uma mulher, negra e pobre, que relata ter feito um aborto por não ter condições de criar mais uma criança - diz que passava fome, inclusive - e que foi denunciada e presa em decorrência disso. Sua fala diz sobre a falta de razoabilidade na criminalização dessas mulheres, pontuando a noção de que "muitas mulheres fazem", de que mulheres fazem isso por desespero e por situação precária financeira, que mães também fazem abortos e que mesmo criminalizadas, fariam novamente se fosse necessário. As mulheres não são identificadas no documentário, ${ }^{14}$ mesmo quando nas entrevistas vemos seu rosto. Não dar nome a essas mulheres se revela uma estratégia discursiva importante, já que os casos nele apresentados pretendem fazer uma asserção sobre todas as mulheres, sobre a condição feminina no Brasil, tratando cada circunstância específica com a potência de uma classe inteira. Aparece aqui a dimensão do título, que usa o afastamento cultural de uma prática como forma de produzir a tensão necessária ao mostrar os casos pontuais com rosto, voz, com mãos nervosas e corpos fragilizados, lágrimas que escorrem dos olhos de todas as mulheres mostradas. O sentido que toma esse título também diz respeito a

14. O documentário não informa se "Maria" é um nome fictício para a paciente de 13 anos. 
forma com que o argumento do documentário presentifica o distanciamento entre a realidade de toda uma classe, sem poder para decidir sobre aquilo que lhe atinge diretamente, e aqueles para os quais se relega, atribui ou que simplesmente detém o poder de decidir, vetar, sancionar e gerar saber sobre essas realidades. Ainda que se possa tomar esses procedimentos dentro de um argumento de denúncia, é importante ressaltar que o documentário reforça, em muitos momentos, a fragilidade associada ao ser mulher. Não tanto como uma constatação de suas vulnerabilidades, embora pareça ser esta a intenção, mas como um dado sobre a subalternidade, visto que serão signos confrontados com percepções de uma sociedade patriarcal.

Os depoimentos que encerram o filme contrastam formal e discursivamente com aqueles dados pelas mulheres que abortaram. Enquanto estes são cercados de um barulho forte (que mistura os sons normais do hospital, como telefone tocando e conversas, ao barulho dos carros que passam na rua), os depoimentos "de especialistas" acontecem em cenários mais privativos, em geral de seus escritórios/consultórios, com paisagem sonora cuidadosamente equalizada para que seja um amparo suave e quase imperceptível para a voz desses. O contraste de espaço, que denota funções e papéis sociais, define os lugares das falas desses atores sociais e suas situações, servindo a um argumento realista, didático, investigativo e denunciatório que $O$ aborto dos outros demonstra propor, mas há, ainda, que se problematizar as vozes em jogo no filme e o que esses procedimentos dizem quando as organizam. Esse borramento, que não parece ser proposital nem em Clandestinas nem em $O$ aborto dos outros, nos leva a pensar sobre a voz enquanto uma autoridade, no sentido próprio da nebulosidade daquilo que esses filmes acabam por dar a ver.

A emergência de tantos documentários construídos em torno de seqüências de entrevistas me parece uma resposta estratégica ao reconhecimento de que nem os fatos falam por si mesmos, nem uma única voz pode falar com autoridade definitiva. As entrevistas tornam a autoridade difusa. Permanece um hiato entre a voz do ator social recrutado para o filme e a voz do filme. (Nichols, 2005b: 57)

O que é possível compreender, a partir da crítica feminista, é que ambas as vozes são atravessadas por uma que as tensiona, as submete, e que nos impede de esquecer que ao se falar de linguagem se está falando de poder também, como relembra Ribeiro (2017). Dentre as vozes postas em cena e vozes que operam o dispositivo do documentário se antevê a tecnologia de gênero que constrói essas imagens, esses corpos, a partir de exercícios inequívocos, embora talvez não propositais, de poder. $\mathrm{O}$ gênero, compreendido aqui como um aparelho semiótico (Lauretis, 1987), é "[...] produto de várias tecnologias sociais, como o cinema, assim como discursos institucionais, epistemologias, e 
práticas críticas; por isto querendo dizer não apenas a crítica acadêmica, mas práticas sociais e culturais mais abrangentes". (Lauretis, 1987: ix) Se a alteridade que emerge enquanto exercício dos olhares desse documentário pode ser um argumento que denuncia o papel reservado às mulheres enquanto corpos passivos perante a discussão sobre o aborto que as exclui enquanto sujeitos; é também nos indícios dessa alteridade que se pode perceber um sobreenquadramento da subalternidade, do qual nos lembra Kilomba a partir de Ribeiro (2017) ao falar de um Outro do Outro. Esse olhar que organiza o dispositivo documental de $O$ aborto dos outros, principalmente, é um olhar de mulher, mas a voz que revela esse olhar não revela, também, a reprodução dos modelos patriarcais a medida em que esconde, num tipo de olhar acadêmico, um lugar de fala de privilégio?

Relegada ao espaço privado, doméstico, a mulher é vitimizada no espaço público (assim como também no privado) e/ou tem sua situação íntima (embora definidora de uma realidade coletiva, de classe) entregue ao escrutínio do público, pois é um juiz que lhe dá o direito ao aborto, ou uma equipe médica $\mathrm{e}$ seu sistema de saúde ali representado que aceitam seu depoimento como verdadeiro, por exemplo. A mulher que relata ter sido denunciada e presa, na parte final do filme, aparece sentada no centro de sua cozinha, inserida no tradicional espaço destinado a ela enquanto mulher e mãe. Os especialistas, quatro homens e uma mulher, falam do local que reafirma suas condições de saber e suas posições hierárquicas enquanto referentes do campo da ciência, do direito ou da prática docente, alguns dos quais juridicamente respaldados para avaliar os casos que lhes chegam amparados previamente pela lei (estupro e risco de vida para a mãe). Esse local também reforça o domínio masculino do espaço público, onde sua individualidade (o consultório/escritório) está confortavelmente estabelecida enquanto um poder sobre a esfera pública e igualmente confortavelmente transitável nessa esfera.

O contraste também é o da identificação, uma vez que são atores sociais mostrados como especialistas sobre uma área a partir de seus nomes e títulos. Há um reconhecimento imediato, subsidiado também pelo próprio imaginário nacional, da validade e, neste caso, de todos os índices relacionados à verdade, dos depoimentos destes: suas falas são sublinhadas por seus nomes e a insígnia a qual molda seus discursos. Falam, nesta sequência, um doutor ginecologista e obstetra, um doutor juiz titular de vara, um doutor médico especialista em saúde reprodutiva, uma doutora médica especialista em saúde da mulher e um professor doutor de obstetrícia de universidade brasileira renomada. É como se a autoridade que o documentário propõe não exercer aparecesse ali representada, marcadamente acadêmica. O peso sobre o termo "doutor/a" no ima- 
ginário nacional remonta à época do Brasil colonial, do contraste social entre os filhos da elite que iam para Portugal (pois estes filhos da elite são nascidos brasileiros) para seus cursos superiores (para tornarem-se "doutores") e os brasileiros comuns, de baixíssima ou nenhuma escolaridade. Doutor/a, no imaginário brasileiro, é uma credencial por definição, dando fé ao interlocutor que porta o título e a tudo aquilo que profere. A civilidade brasileira está construída sobre essas bases e o debate político ainda tem heranças de uma divisão intelectual de classes que permite aos que tem "douto conhecimento" a detenção de uma verdade inquestionável. Considerando-se, especificamente, a questão do aborto, a cultura patriarcal que rege os procedimentos relacionados às realidades reprodutivas está totalmente imbuída de uma realidade social construída pelas noções hierárquicas relacionadas ao sexo (homens) e status (titulação e classe econômica). Assim, o contraste em $O$ aborto dos outros se dá entre uma verdade emocional e material, de mulheres estupradas, agredidas, enlutadas, sofrimento do qual elas falam; e uma verdade científica, jurídica, dos saberes credenciados, da qual em geral os homens são signatários/representantes. No subtexto, o documentário revela uma noção da realidade brasileira dentro da qual se compreende que o apelo das mulheres, ainda que por seus direitos humanos, só deverá receber qualquer atenção caso seja amparado em apoio fortemente elitizado e privilegiado. Ou busca amparo e legitimidade nesses doutos conhecimentos masculinos, o que parece contraditório.

\section{Morte e vida Severina}

Se a estratégia de resistência de $O$ aborto dos outros e Clandestinas recupera a contação de histórias como uma prática política de construção do sujeito histórico mulher ao mesmo tempo em que esses documentários constroem uma subjetividade feminina, um olhar específico; Uma história Severina ${ }^{15}$ (2005), de Débora Diniz e Eliane Brum, é outro filme brasileiro que reescreve na arte da contação de histórias da tradição nordestina esse sujeito de quem não se ouve falar senão através de um neutro, masculino, universalizante. E, neste caso, um neutro não-nordestino. Este documentário está centrado em uma mulher, Severina, trabalhadora rural do interior do Pernambuco, que está grávida de um feto anencéfalo. Mãe de um menino de quatro anos e casada, Severina pleiteia na justiça o direito de interromper uma gestação de uma criança inviável. A história dela é exemplar porque encontra-se num limbo da lei e ilustra a complexidade das compreensões acerca da moralidade ou até mesmo da legitimidade do ato do abortamento. A particularidade de seu caso é de tal forma

15. Disponível em: https://youtu.be/65Ab38kWFhE. 
absurda que a estrutura do documentário busca na literatura de cordel não só a referência óbvia à localização de Severina, como a metáfora potente de um discurso que a torna exemplar e, ao mesmo tempo, o alegoriza. O cordel é uma tradição gráfica e literária do Nordeste brasileiro que, em Uma história Severina, une-se à tradição musical de modo que localize histórica e culturalmente o sofrimento desta mulher, assim como também esteticamente. Como interpretação popular que herda formas e estruturas da colonização portuguesa e das tradições visuais e orais medievais, o cordel fala da vida comum do povo do sertão nordestino através de um folclore rico em religiosidade, mitos e lendas. As histórias que os folhetos do cordel contam (que são cantadas também, em ritmo de trova) são épicas e exemplares, formas populares análogas aos mitos gregos, e esse dizer no documentário sobre Severina fala de uma trajetória mítica que se pretende argumentar enquanto ilustrativa de uma realidade comum - às mulheres, às sertanejas, às gestantes pobres do Nordeste, não raro analfabetas como esta mulher. $\mathrm{O}$ título do filme também evoca uma tradição estética que nos remete ao modernista poema de João Cabral de Melo Neto, Morte e vida Severina. Tanto o Severino do poema quanto a Severina do documentário são icônicos por serem um nome comum da região sertaneja brasileira. O que o poema escrito nos anos 50 vai sedimentar, ajudando-nos a entender algumas escolhas de Uma história Severina, é a relação muito forte entre a miséria geograficamente localizada desse povo e a maneira como se enxerga o Nordeste no resto do Brasil. O documentário usa a cultura do cordel, o nome da mulher, sua realidade indiscutível e o imaginário sobre esta região para que a particularidade dessa história não impeça que se veja Severina como a questão social da mulher pobre e analfabeta frente ao "Brasil dos bacharéis", como diria Machado de Assis, que decidem seu destino e, sobretudo, julgam seu sofrimento um detalhe estatístico. Faz, assim, sua primeira asserção de uma alteridade - que transita entre a empatia e o enquadramento de uma realidade quase de fábula, sobre a qual a instância documental assume exercer essa alteridade marcada pelo óbvio distanciamento de realidades.

Nessa relação entre um Nordeste ora realista ora caricato, literário, e o (resto do) Brasil dos privilégios se dá a outra forma de argumentação da qual o dispositivo de Uma história Severina lança mão. Severina descobre, aos quatro meses de gestação do segundo filho, que seu bebê não é viável. É internada na capital, Recife, para, na manhã seguinte, ter interrompida sua gravidez, já que poucos meses antes esse tipo de procedimento havia sido permitido por decisão do Superior Tribunal Federal (STF). No dia seguinte, o médico que a atenderia desiste do procedimento pois lê no jornal que uma (outra) liminar do STF acabava de cassar a decisão. O documentário recorta a história de Severina 
a partir dessa situação, quando passa a recorrer à justiça para que possa fazer o aborto. Sua história começa a ser contada com uma apresentação que também evoca o poema de Melo Neto ${ }^{16}$ : "Sou Severina, filha de Dedé, filha de Maria, moro [...]". A música tema acompanha desde a introdução dos personagens, e foi feita especificamente para a história que será contada. ${ }^{17} \mathrm{O}$ que se segue à apresentação da família de Severina e o título do documentário é uma sucessão de imagens em preto e branco de páginas de importantes jornais do país com manchetes que falam sobre a decisão, com validade nacional, e aquela que se refere à liminar que cassa a decisão. A música tema canta os sete meses de dor e sofrimento do casal, detalhe que o documentário explica em texto branco sobre fundo preto, sintetizando a coincidência entre as liminares e o caminho de Severina. A busca pelo direito a interromper sua gestação é contada em atos, sublinhando a tradição popular nordestina, uma metáfora deste documentário que reforça um padrão de olhar sobre o Nordeste como sobre uma encenação da vida, um teatro. Não é necessariamente com viés de superioridade que a cultura nordestina costuma ser vista através dessa tradição de fábula, mas essa relação no imaginário brasileiro tem seus efeitos redutores e desumanizadores. O subtítulo na tela, ladeado pela xilogravura, típica ilustração do cordel, pontua esse paralelo. O primeiro ato da trajetória de Severina chama-se "Os Ministros" e dá conta dos depoimentos dos ministros do STF em seções que discutiram o assunto (matéria da liminar e de sua cassação). A voz do ministro do Supremo Nelson Jobim anunciando a decisão surge, em off, sobre a tela com o nome do ato, que antecede em alguns segundos a imagem da discussão na plenária, que a câmera do documentário enquadra sobre o enquadramento da tela da TV que, também em preto e branco, transmite a seção pelo canal da TV Justiça.

Este ato é usado de forma que o argumento do documentário coloque em jogo as falas que se contradizem a partir de uma montagem que lembra o estilo eisensteiniano, segundo o qual a justaposição de dois signos ou discursos que se contradizem produz um discurso terceiro (Eisentein, 2002). O discurso terceiro aqui ressalta o distanciamento entre a realidade, próxima, mostrada em cores, captada diretamente pela câmera; e a judicialização de uma causa alienada daqueles aos quais interessa e sobre cujas vidas produz influência nefasta, sobreenquadrada a partir da moldura da TV, em preto e branco, com linguagem formal. Esse distanciamento é um dos principais argumentos do documentário, que também confronta os depoimentos orais dos ministros (e seu teor, seu

16. "O meu nome é Severino, como não tenho outro de pia. Como há muitos Severinos, que é santo de romaria, deram então de me chamar Severino de Maria; como há muitos Severinos com mães chamadas Maria, fiquei sendo o da Maria do finado Zacarias. [...]"

17. "As sementes da dor e sofrimento", de Mocinha de Passira. 
conteúdo) com os depoimentos de Severina e do marido Rosivaldo e os documentos médicos que o casal apresenta para quem os entrevista. Essa presença em ausência de quem documenta, de quem entrevista, aproxima quem produz o documentário da realidade documentada, o que é de suma importância para que se produza a empatia necessária para com a história de sofrimento de Severina. É aqui que, como os outros documentários aqui mencionados, transgride algumas formas do documentário participativo enquanto adere a outras, estabelecendo um diálogo que marca a posição política de mulheres documentaristas - aquelas que usam o dispositivo do documental e produzem um discurso ora a partir de uma linguagem canonizada e, portanto, masculina, ora subvertendo (mais ou menos) essa linguagem.

Quando assistimos a documentários participativos, esperamos testemunhar o mundo histórico da maneira pela qual ele é representado por alguém que nele se engaja ativamente, e não por alguém que observa discretamente, reconfigura poeticamente ou monta argumentativamente esse mundo.

[...]

Documentários participativos [...] envolvem a ética do encontro, um encontro entre alguém que controla uma câmera de filmar e alguém que não a controla. [...] Que laços unem cineasta e tema e que necessidades os separam? (Nichols, 2005a: 54-5).

Os laços que aproximam as documentaristas de Severina e de sua história são os laços de classe, mas suas realidades as separam em muitos sentidos também. Enquanto enquadram uma mulher, como elas, Débora e Eliane também estão, cabe ressaltar novamente, enquadrando "um Outro", a quem pretendem ou propõem representar. Advogam em favor desta mulher que não detém sequer os meios mínimos de produção, ainda que essa produção pudesse ser apenas contar sua história com "a linguagem que importa" no país dos bacharéis. As cineastas formalizam, em linguagem que uma elite possa compreender, aquilo que também deixam a cargo da tradição oral, presente na canção de Mocinha e sua relação com uma cultura nordestina. A questão de Bill Nichols (2005a) ajuda-nos a definir em que espaço ético transitam os argumentos do documentário e a relação entre essas mulheres, privilegiadas - e deter o poder da câmera é seu privilégio maior - que tem o interesse complexo em denunciar a tragédia das severinas, das mulheres que sofrem as consequências de uma ordem que lhes tira a autonomia corporal mas também a possibilidade de ter voz, já que não dominam a linguagem desses homens. Como o diria esse autor, as cineastas aqui "unem forças" com aqueles que representam sua argumentação. E essa noção de Nichols (2005a) dá a ver que a própria modalidade participativa transgride o imaginário a partir de onde perceberíamos essas cineastas como representando Severina (como advogadas de sua causa), e não, como Ni- 
chols parece sugerir, como Severina representando para as cineastas a matéria da qual o documentário parte para tecer seus argumentos sobre o aborto.

A forma com que Débora e Eliane constroem sua asserção em Uma história Severina é a de um documentário cuja estrutura diz respeito a um tipo específico de enunciação, que tem relação com uma "política de identidade" (Nichols, 2005a), mas transita entre um falar de si e um falar de "um outro" com o qual se tem uma dívida. E o feminismo acadêmico, aqui representado por uma elite intelectual de que fazem parte as cineastas, deve advogar em favor das mulheres que estão distanciadas da academia, de modo que cumpra com uma responsabilidade de reduzir as desigualdades não apenas representadas pelo poder dominado pelos homens e o estatuto de objeto das mulheres, mas também pelo abismo que separa homens brancos de elite, doutores juízes, ministros de toga, detentores de poder sobre os corpos das mulheres; e severinas pobres, analfabetas, cujos corpos carregam materialmente o feto anencéfalo que é matéria abstrata da longa discussão transmitida pela TV Justiça. É a partir disso que faz sentido o que Jean-Louis Comolli (2008: 200-201, grifos no original) diz sobre o que o cinema documentário nos ensina:

Se é justamente a relação documentária que é filmada, os dois lados dessa relação não podem deixar de se marcar como elementos de escritura. O que se produz diante da câmera e de seu fato, mas também o que se passa atrás dela: o espectador é confrontado com a representação das duas faces da relação $[\ldots]$.

Uma história Severina monta, no documentário, um tribunal dividido entre as argumentações desses homens de toga e a defesa e provas apresentadas por este casal que não quer esperar por uma já conhecida morosidade da justiça, em especial quando se trata do tema do aborto. A espera de Severina demonstra claramente o abismo entre a abstração do debate dos ministros e a realidade material sobre os corpos femininos (e seu psicológico, sua estrutura emocional). Esse abismo é formalizado no documentário a partir da montagem que alterna a fala dos membros do STF (algumas das quais em favor da decisão de permitir o aborto em caso de feto anencéfalo) e a fala de Rosivaldo e Severina. Esse modo participativo ilustra a recusa "[...] a transformar os destituídos em vítimas à espera de caridade. As mulheres exigiram a atenção da câmera, em vez de subordinar suas vozes a um argumento ou perspectiva que pertencesse unicamente ao cineasta" (Nichols, 2005a: 194). Neste caso, as mulheres tomaram as câmeras e as colocaram a favor de mulheres para as quais a câmera nunca estará disponível. Se os documentários engajam-se no mundo através da representação, como diz ainda Nichols, a forma com que Uma história Severina o faz é representando o mundo como "[...] um advogado representa os interesses de um cliente [...]" (2005a: 30), dispondo 
ao espectador um ponto de vista ou uma interpretação determinada de provas. "Nesse sentido, os documentários não defendem simplesmente os outros, representando-os de maneiras que eles próprios não poderiam; os documentários intervêm mais ativamente, afirmam qual é a natureza de um assunto, para conquistar consentimento ou influenciar opiniões." (Nichols, 2005a: 30).

$\mathrm{O}$ momento mais dramático desta montagem faz referência a um contexto no qual a criminalização do aborto é amparada por uma percepção moral dos fetos enquanto pessoas, comparando o aborto ao assassinato de uma pessoa já nascida, noção contrariada pela ciência e pelos argumentos éticos que clamam os direitos básicos e humanos das mulheres. Na alternância entre a fala dos ministros e de Severina e Rosivaldo, o documentário apresenta o tom teatral dado pelo então procurador-geral da República, Cláudio Fontelles, quando apela emocionalmente à formação do feto, mencionando o nariz, a boca, o sangue e o coração batendo. Em seguida, seu equivalente no espaço contíguo ao da câmera, o espaço do real, vemos o lugar histórico de Severina, cujo marido diz que se vê pelo ultrassom a ausência, no feto, da parte de cima da cabeça. Rosivaldo mostra o ultrassom para a câmera. A fala do marido traz a argumentação do procurador-geral para a realidade do feto no corpo de Severina. $\mathrm{O}$ trecho que se segue a este retorna à assembleia dos ministros, dando a palavra a Carlos Ayres Britto, que diz que "o que se tem no ventre materno é algo, mas algo que jamais será alguém". Esta fala aproxima-se de Severina na medida em que percebemos o sotaque do ministro, nordestino, que de certa forma representa uma representação. Embora não seja uma mulher, sua origem está mais próxima de Severina e portanto, no contexto em que o documentário busca caracterizar a "severinidade" desse sofrimento - que é uma agudização da marginalização - por meio de uma construção ética da estética da expressão cultural e artística do sofrimento dos sertanejos, torna-o apto a dizer por ela. Porém, tanto essa circunstância quanto a da caracterização dessa "severinidade" dão a ver, no deslocamento que essas alteridades significam, uma falência da própria representação. Ora Severina é representada por um homem de toga, ora sua história (e "a história dos severinos") é representada por mulheres brancas de classe média. Se essa relação envolve a ética do encontro, como o diria Nichols (2005a), é importante ressaltar que esse encontro também reproduz uma estética da alteridade que, especialmente no que tange o próprio constructo cultural brasileiro sobre os elementos aqui envolvidos, é uma estética que reforça essa alteridade, de certa forma. Roland Barthes dizia, em Mitologias, que o pequeno-burguês é incapaz de imaginar o Outro. "[...] O outro, seja qual for, é reduzido ao mesmo. [...] O outro é transformado em puro objeto, espetáculo, marionete [...]." (Barthes, 2001: 171-172) Se retomarmos 
Djamila Ribeiro (2017), a respeito de lugar de fala, podemos considerar que Uma história Severina dá lugar para essa Severina específica contar de sua dor a partir de sua vivência, porém é visível que suas falas são arranjadas a partir de uma visão sobre a "severinidade" que dá a ver a própria distância entre Severina e as cineastas que conduzem esse relato. Assim, surge uma questão, adiada ao longo deste artigo, que é a questão sobre esse lugar. As cineastas estão mais próximas dos "homens brancos de classe média" ou dessas mulheres, especialmente de Severina e daquelas em $O$ aborto dos outros?

A alternância da montagem entre Severina e os Ministros do STF também dá conta de uma defesa da separação entre justiça e Estado e religião, em um arranjo que abre espaço a uma argumentação sobre a laicidade esperada do STF mas, sobretudo, sobre os pesos que "as verdades" tem, nesses casos. A verdade legitimada da justiça dos homens de toga, sobreenquadrada a partir da tela do canal oficial de TV, e a verdade daqueles para quem a realidade e dignidade humanas se sobrepõe a qualquer moralidade religiosa. Um ministro defende a laicidade da casa, Rosivaldo diz que eles fariam o aborto ainda que o padre dissesse que é pecado. No "tribunal" metafórico no qual este documentário deposita sua argumentação, o que se está colocando em jogo tem muitas camadas, pois evoca 1) as próprias tradições militantes de um cinema que usa estratégias formais de convencimento (tais como essa alternância eisensteiniana); 2) as condições culturais e sociais dentro das quais o estatuto de "verdade", mesmo relativo, do documental deve ser repensado, uma vez que os "tipos" de verdade tem poderes desproporcionalmente assimétricos nesse contexto; 3) o discurso feminista ou engajado na causa das mulheres que deve dar a ver uma realidade material e emocional que contrasta com a abstração da lei; e 4) a capacidade de formular um conhecimento que supere as assimetrias e seja compreendido pela espectatorialidade.

Para sustentar sua tonalidade central, que é demonstrar que a argumentação do STF contrária ao direito ao aborto em casos em que o feto é anencéfalo está equivocada porque não leva em consideração o sofrimento de pessoas que existem, que são os sujeitos desse direito humano básico à dignidade, Uma história Severina se vale de uma estratégia de contraste de realidades que tensiona a própria natureza desse contraste. A argumentação da lei não tem opinião contrária a de Severina ou do feminismo ou das mulheres pelo direito à escolha com relação ao aborto em si. O problema é que a lei, e seus signatários ou defensores, não percebem a realidade da mesma forma, e isso fica claro quando vemos que os ministros são todos homens e o teor de seus argumentos contra $\mathrm{o}$ direito ao aborto de anencéfalo está centrado em uma concepção que não considera $a$ verdade das mulheres, mas uma abstração dessa verdade, subsidiada 
por uma tradição de representação da experiência de ser mulher que é dada a partir de quem não o é. Esse abismo perceptivo é encenado neste documentário pelo abismo formal, especialmente quando coloca em cena, de forma artificial - através da montagem - uma fala apresentada como cruel diante de uma fala com forte apelo emocional. Esta confrontação estética e de linguagem é o que nos permite compreender que Uma história Severina opera em várias frentes argumentativas (por necessidade) e que uma delas é demonstrar a falta de fundamento na razão dos homens do STF. O que é dizer que este documentário oferece uma verdade que em si já tem peso (o sofrimento de Severina ao ter que levar a termo uma gestação para então parir um filho morto ou por morrer) e uma verdade que está sobre todos os casos específicos, que é a necessidade de se deslocar as percepções centradas no homem que costuram a cultura. Diz o ministro Cezar Peluso que não está certo sobre o fato de que o feto anencéfalo é "um condenado a morte". "Todos o somos", diz, com entonação que deriva de um conhecimento acadêmico da filosofia que ignora a especificidade em questão. Neste momento, as cineastas se distanciam desse "academicismo" ao usar esta fala na montagem de forma a denunciá-la. Com tom irônico, Peluso continua, dizendo que "o sofrimento em si não é alguma coisa que degrade a dignidade humana", fazendo referência a um dos principais argumentos em favor do direito da mulher e negando sua validade. A imagem que se segue é a de Severina chorando, dizendo que perde o sono pensando (na perda indiscutível do filho que carrega).

É importante lembrar que os depoimentos dos ministros transmitidos pela TV Justiça se dão no mesmo tempo cronológico do início da peregrinação de Severina pelo direito ao aborto depois de o hospital lhe ter negado o procedimento, o que aproxima a verdade da história desta mulher de uma verdade que pode ser documentada - tanto pelas páginas de jornais, no início do filme, quanto pela transmissão ao vivo do debate no Supremo Tribunal. ${ }^{18}$

Os atos que se sucedem na peregrinação de Severina para conseguir o direito de interromper a gestação dizem respeito ao demonstrativo sobre a burocracia brasileira, que de certa forma está fortemente vinculada culturalmente à abstração e alienação da justiça, pois não leva em consideração que esta mulher, já no meio da gestação, não pode esperar por processos lentos. A câmera acompanha sua trajetória fazendo analogia entre sua busca por justiça e a peregrinação também tão tradicional na história dos retirantes nordestinos e de

18. A relativamente recente (2012) inclusão do aborto de feto anencéfalo entre as exceções da lei que criminaliza a interrupção voluntária da gravidez foi resultado de um processo de oito anos que também não contou com debate amplo. Desde 2004 o Supremo Tribunal Federal (STF) discutia sobre a questão, a partir da situação emblemática em que um dos ministros da casa concedeu uma liminar permitindo o direito à escolha da gestante neste caso e três meses depois a liminar foi cassada por outro membro do STF, como vemos no documentário. 
suas alusões à via-crúcis cristã. Somente aos sete meses de gravidez Severina consegue a autorização do Fórum para o aborto que, em seu caso, será tão sofrido quanto o seria o nascimento a termo. No hospital, depois de esperar ainda mais por ser recebida no plantão médico por profissionais que alegam objeção de consciência, Severina tem seu parto induzido e sofre suas dores por mais de 30 horas, percurso que a câmera acompanha como nos documentários de observação. O faz de longe, com enquadramentos precários - e, por isso, remetendo à obscenidade daquele sofrimento que é, ao mesmo tempo, irrepresentável -, com zoom instável e que diz muito sobre a situação ética de quem a opera (Sobchack, 2005). Subverte, no entanto, o dispositivo observativo no sentido de que o faz quando o contexto pungente e a documentação já produziram para o/a espectador/a a história de Severina, uma história Severina. Essa opção retórica pode ser uma maneira de construção discursiva que se desloca da retórica masculina, como também vemos nos dois primeiros documentários mencionados. De qualquer forma, os efeitos que produz enquanto subverte a lógica do modo observativo são da ordem da representação da morte. Diferente de documentários de argumentação "pró-vida", que recorrem à imagem-intensa (Ramos, 2005 e Sobchack, 2005) como forma de atribuir valor de crime capital ao aborto, objetificando fetos enquanto esperam empatia por suas vidas abreviadas; aqui o modo documental de observação é usado como figura de linguagem para, dentro do modo participativo, criar um terceiro signo, no qual possa construir a ideia de uma intensidade, de uma experiência estética limite na qual o foco está sobre o sofrimento da mãe, que vê seu filho morto, ainda na mesa de parto, depois de carregá-lo inviável por sete meses. Nesta sequência, forte demais para os mais sensíveis, vale o peso final de uma argumentação que vem sendo costurada desde o princípio, a partir da qual tivemos inúmeras chances de aderir à Severina, empaticamente, para então demonstrar, pelo testemunho da câmera, o auge de seu sofrimento de mãe. Só a vemos como mãe, inclusive, porque assim foi construída durante todo o documentário, no qual até diz textualmente da grande importância de um filho dada sua experiência de mãe de um menino de quatro anos. O modo de olhar sobre a sequência do trabalho de parto e parto de Severina se inscreve em um espaço ético que é, aqui, político também. A observação aqui tem relação com um olhar impotente, uma das formas de atividade visual que colocam em discussão a ética documental. Nessa "inscrição do espaço ético", Vivian Sobchack (2005) está tratando da imagem da morte, e de várias formas podemos tratar aquele evento em Uma história Severina como morte. A morte do bebê, que era inviável fora do útero da mãe; a agonia da mãe que está parindo um natimorto; a morte enquanto sua analogia escatológica com o nascimento. 
Porém, na subversão política desse discurso, o documentário pretende mostrar sua impotência e a impotência de Severina perante o destino que lhe agride no âmago da dignidade humana. "O 'olhar impotente' perante a morte é codificado em sinais de distância técnica e física do evento. [...] A distância e a impotência que ela confere são denotadas não apenas pelo plano geral, mas também pelo uso freqüente das lentes de zoom." (Sobchack, 2005: 150, grifos no original) Assim, quando dá a ver a imagem do bebê morto enrolado em cobertas do hospital, o qual é mostrado para Severina brevemente, podemos sentir empatia pelo sofrimento desta mãe, e não primordial e unicamente pelo signo da morte que é a imobilidade e silêncio do bebê.

Ela não consegue tocar na criança, repetindo, enquanto chora, "meu filho, meu filho". Após essa cena, onde vemos que a câmera busca evitar a intensidade do indiciamento da morte sobre o bebê, vemos Severina chorando muito e, enquanto fala ao telefone com o marido, repete: "ele tá morto, ele tá morto". A partir daqui, a câmera parece voltar ao seu objetivo de evitar a morte visível pois o sofrimento que enquadra enquanto mostra a fala de Severina se sobrepõe à morte indicial. "O filme documentário [...] se caracteriza por uma excessiva evitação visual da morte, e, quando a morte é representada, a representação parece exigir uma justificação ética." (Sobchack, 2005: 141) A presentificação da morte, inscrita no verbo da frase "ele tá morto", enfatiza a circunstância violenta em que se encontra essa mulher, que sabe, um tanto abstratamente, que seu bebê não é viável. A coloca no mesmo tempo que a câmera e o espectador, que vivem esse presente intenso (Ramos, 2005) com ela e portanto sentem a impotência da morte tal qual essa mulher, apesar de todos sabermos do que estava por acontecer. A questão aqui está em como o documentário tensiona uma morte anunciada construindo-a como morte que irrompe o espaço visível do documental de maneira súbita de forma a retirar do corpo morto o peso de um sofrimento e atribuí-lo, por definição, a quem de direito (a mãe), segundo o que demonstra entender a montagem desse documentário. Sua maternidade enlutada é a potência audiovisual dessa transferência, que é enfatizada quando, depois de dizer ao marido que o bebê está morto, pergunta pelo filho: "cadê Valmir?". Aqui parece se acomodar a justificativa ética da imagem da morte que a câmera não pode evitar.

Embora sem certidão de "nascimento", o bebê é enterrado em um caixão branco, vestindo roupas de recém nascido brancas que Severina comprou antes de entrar no hospital. A foto tirada da criança no caixão desrealiza a pungência da morte, notificando-nos de um luto, e por ser um luto, enfatizando o quanto a morosidade da justiça brasileira permitiu que, em vez de um aborto, Severina sofresse um parto em toda sua dimensão de gravidade e expectativa. Assim, 
obriga-nos a ver que o sofrimento imposto a ela foi o de uma violência inimaginável: obrigá-la a gestar uma criança virtualmente morta, parindo um filho com o qual nunca voltará para casa, sem condições de resolver um luto que precisa das práticas da cultura para ser resolvido. Enquanto familiares enterravam o caixão branco do bebê, Severina não estava presente. Diz que nem sabe onde está a cova do filho. Ao contrário do que diz o ministro do STF, a dignidade humana é ferida irrevogavelmente do início ao fim do processo, usando o útero de Severina para o cumprimento ritual de uma lei que tem sentido no abstrato poético dos homens de toga da assembleia, mas não é senão uma violência de Estado contra a mulher. Antes dos créditos finais, Severina diz que "[tudo o que aconteceu] é feito uma história". Em sua tentativa de afastamento do sofrimento, fica alienada da violência a que foi submetida, tratando por "história" a ficção e a ficcionalização dos fatos. Ajuda a confrontar, assim, o argumento documental com a impessoalidade de uma ficção. Essa impessoalidade à qual é condenada por não ter agência para decidir evitar o próprio sofrimento terrível, o qual, por sua vez, também é visto como uma ficção, um argumento que abstrai a realidade ao criar uma encenação genérica sobre dados aos quais não se tem acesso emocional real. Mas não tem, esse documentário, também a forma de "uma história"? História aqui não no sentido da que Severina conta sobre ela mesma e seu sofrimento, mas de ficção, de fábula.

Depois dos créditos, vemos o casal assistindo ao documentário em primeira mão, pela TV. Reforça-se, assim, os múltiplos enquadramentos sobre essa "história". Severina chora, enquanto Rosivaldo diz que se a pessoa que assistir aquilo for humana vai sentir alguma coisa. Faz, assim, uma remissão ao espectador, mas também a uma esperançosa hipótese que vive no núcleo de todo documentário, que é afetar as pessoas. Retomo, assim, Comolli (2008), quando este diz que o espectador é confrontado com os dois lados dessa relação documentária, sendo compelido a adquirir uma consciência de como seu próprio olhar funciona. Em uma última estratégia retórica, o filme busca explorar a própria importância da contação de história como veículo para o debate sobre a realidade e experiência das mulheres. Esta foi, afinal, a argumentação central aqui. A busca dos três documentários é a de construir uma mulher sujeito, humana, para que, assim como diz Rosivaldo, não haja quem não sinta sobre uma realidade de morte e vida no Brasil. Na reflexão sobre essas estratégias e procedimentos documentais, no entanto, surge a questão de como essa retórica constrói essas alteridades. 


\section{Considerações finais}

O percurso teórico-metodológico que colocou aqui em debate os discursos, estratégias e/ou procedimentos documentais no sentido de refletir sobre as relações entre a crítica feminista, um cinema feito por mulheres e a temática do aborto no Brasil iniciou-se a partir de circunstâncias políticas cruciais tanto para as mulheres quanto para o país na atual conjuntura política. A necessidade de discutir o papel do documentário a partir da crítica feminista, especialmente uma prática documentária de mulheres sobre mulheres, é de grande vulto. $\mathrm{O}$ que se compreende, dadas as reflexões aqui dispostas, é que apesar de representarem um deslocamento de olhares crucial em se tratando de documentários feitos por mulheres, os três filmes analisados dão a ver, também, uma voz que tenciona a representação ela mesma de mulheres que fazem/fizeram aborto por outras mulheres, documentaristas. Esse tencionamento se constrói a partir de indícios discursivos nos filmes que revelam mais do que a própria discussão sobre a alteridade na relação entre quem é representada (a mulher que faz/fez aborto), quem a representa (as documentaristas) e quem é espectador(a), mas a própria relação documental em si. A reflexão teórica e crítica sobre essa relação permitiu que se percebesse que há um jogo das vozes do documentário que ora tomam o lugar de mulher, um Outro também, que tem aí a legitimidade de um lugar de fala que também a aproxima do Outro que está sendo representado; ora deixam antever seu lugar como mulheres sujeito, que são privilegiadas com relação a essas que representam. Essas vozes são signo de um embate que é significativo no interior do feminismo, e da própria teoria crítica feminista, que dá a ver a questão do problema da representação construída sobre uma categoria universal de mulher - que reflete a própria universalização que critica no discurso dominante (jurídico e científico, por exemplo), centrado no homem como modelar.

Os três documentários, cada um a seu modo, transitam entre sua posição política empática para com as mulheres que fazem/fizeram abortos e a posição de seus privilégios, para os quais essas mulheres são Outros. Assim, colocam em cena, através dessas vozes muitas vezes conflitantes (outras vezes complementares), as distâncias entre os vários feminismos, que demandam importante discussão sobre que lugar ocupam na crítica feminista as vozes negras, das mulheres pobres, e qual o olhar do feminismo acadêmico sobre as questões centrais das lutas das mulheres, como o direito ao aborto. Ao transitarem por essas posições, esses filmes cumprem, ainda, com outro papel: problematizar a própria relação documentária, nos limites entre o falar delas e o falar de si mesmas. Na alternância entre esses lugares, os documentários aqui analisados evidenciam o próprio procedimento do feminismo acadêmico - no qual, cabe 
reforçar, estou inserida e contra o qual ora me volto -, que acaba por legitimar vozes já legitimadas, como o faz em $O$ aborto dos outros; ou por objetificar e espetacularizar sofrimentos como se fossem fábulas, como em Uma história Severina. A própria construção deste texto traz as marcas da nevralgia que esses conflitos provocam na militância feminista, pois permitem que se note que a teoria crítica feminista demanda esforços que quase sempre resultam em muitas questões não respondidas. Ainda que representem importantes instrumentos no sentido de aproveitarem seus privilégios para dar voz a quem não a tem, denunciando a violência patriarcal, esses documentários permitem também que o feminismo acadêmico possa fazer uma importante reflexão sobre o papel ético da representação.

\section{Referências Bibliográficas}

Barthes, R. (1989). Mitologias. Rio de Janeiro: Bertrand-Brasil.

Beauvoir, S. de. (2009). O segundo sexo. Rio de Janeiro: Nova Fronteira.

Comolli, J.-L. (2008). Ver e poder. A inocência perdida: cinema, televisão, ficção, documentário. Belo Horizonte: Editora UFMG.

Eisenstein, S. M. (2002). A forma do filme. Rio de Janeiro: Jorge Zahar Editor.

Federici, S. (2017). Calibã e a bruxa. Mulheres, corpo e acumulação primitiva. São Paulo: Elefante.

Flax, J. (1992). Pós-modernismo e relações de gênero. In H. B. de Hollanda (org.), Pós-modernismo e política (pp. 217-250). Rio de Janeiro: Rocco.

Lauretis, T. de. (1987). Technologies of gender. Essays on Theory, Film, and Fiction. Bloomington (IN): Indiana University Press.

Lauzen, M. (2017) Women in Independent Film, 2016-17. Center for the Study of Women in Television \& Film. Disponível em: http://womenintvfilm.sds u.edu/wp-content/uploads/2017/05/2016-17_Women_in_Independent_Fi $1 \mathrm{~lm} \_$Report.pdf

Lins, M. \& Mesquita, C. (2008). Filmar o real. Sobre o documentário brasileiro contemporâneo. Rio de Janeiro: Jorge Zahar Ed.

Mulvey, L. (1989). Visual Pleasure and Narrative Cinema. In L. Mulvey, Visual and Other Pleasures. Language, Discourse, Society (pp. 14-26). Londres: Palgrave Macmillan.

Nichols, B. (2005a). Introdução ao documentário. Campinas, SP: Papirus.

Nichols, B. (2005b). A Voz do Documentário. In F. P. Ramos (org.), Teoria Contemporânea do Cinema (pp. 159-225). São Paulo: Senac, v II. 
Penafria, M. (2005) O filme documentário em debate: John Grierson e o movimento documentarista britânico. Estética e Tecnologia da Imagem, 1, 185-195. UBI. Disponível em: www.bocc.ubi.pt/pag/penafria-manuelafilme-documentario-debate.pdf.

Perrot, M. (2017). Minha história das mulheres. São Paulo: Contexto.

Ramos, F. P. (2005). A cicatriz da tomada: documentário, ética e imagemintensa. In F. P. Ramos (org.), Teoria Contemporânea do Cinema (pp. 159-225). São Paulo: Senac, v II.

Ribeiro, D. (2017). O que é lugar de fala?. Belo Horizonte: Letramento: Justificando.

Saffioti, H. (2015). Gênero patriarcado violência. São Paulo: Expressão Popular: Fundação Perseu Abramo.

Sobchack,V. (2005). Inscrevendo o espaço ético: dez proposições sobre morte, representação e documentário. In F. P. Ramos (org.), Teoria Contemporânea do Cinema (pp. 145-157). São Paulo: Senac, v II.

\section{Filmografia}

Abortion Stories Before Roe v. Wade (2017), de The Scene.

Clandestinas (2014), de Fadhia Salomão.

Jogo de cena (2007), de Eduardo Coutinho.

O aborto do outro (2008), de Carla Gallo.

Uma história Severina (2005), de Débora Diniz e Eliane Brum. 